\title{
GROWTH AND YIELD PERFORMANCES OF TURMERIC (Curcuma longa) GROWN IN DRY ZONE OF SRI LANKA AS AFFECTED BY PLANTING SPACE, GROWING MEDIA AND SHADE
}

\author{
Vidanapathirana N.P. ${ }^{* 1}$, Subasinghe S. ${ }^{2}$, Sunil K. ${ }^{1}$, Ketipearachchi K.G. ${ }^{1}$, Siriwardana A.J.M.C.M. ${ }^{1}$ and Bandusekara B.S. \\ ${ }^{1}$ Institute for Agro-Technology and Rural Sciences, Hambantota, Sri Lanka \\ ${ }^{2}$ Department of Crop Science, Faculty of Agriculture, University of Ruhuna, Mapalana, Kamburupitiya, Sri Lanka \\ *Corresponding Author: nisansala@ uciars.cmb.ac.lk ( iD https://orcid.org/0000-0003-1187-5681) \\ Received: 07.01.2022; Accepted: 29.01.2022; Published: 31.01.2022
}

\begin{abstract}
Turmeric is mainly grown as monocrop or intercrop in wet and intermediate zones of Sri Lanka. However, promoting the dry zone turmeric cultivation under intensive irrigation and proper shade conditions could address the increased demand for locally produced Turmeric and create an extra potential for exportation. Therefore, it is essential and urgent need to find out the feasibility of growing Turmeric in dry and semi-arid areas. Thus, this study focus evaluate the effect of different plant spacing, growing media, and shade on growth and yield performances of Turmeric in Hambantota district,belong to semi-arid zones. The split-plot design was used. The main plot consisted of two shade levels (30\% shade and without shade), and subplots were assigned three spacing ( $30 \times 20 \mathrm{~cm}, 30 \times 30 \mathrm{~cm}, 30 \times 40 \mathrm{~cm})$ and two different potting media (Cow dung: Topsoil - 1:1, Cow dung: Topsoil: Sand - 1: 1: 0.5 replicated by three times. Results revealed no significant interaction of shade, planting spacing and planting media on plant height, leaf length and yield. However, the interaction effects were found between shade and planting media on plant height and shade and planting spacing on rhizome yield. The significant improvement of yield and plant height in plants established in cow dung: topsoil; 1:1 media under shade and plant grown in $30 \times 30 \mathrm{~cm}$ plant spacing. The significantly highest leaf length was recorded from the plant established under 30\% shade compared to without shade and the highest number of sprouts was recorded from the plants in cow dung: topsoil; 1:1 media. The significantly highest yield were recorded from the plants established in both $30 \times 30 \mathrm{~cm}$ and $30 \times 40 \mathrm{~cm}$ spacing under shade. Thus, the results could be concluded that plants are grown in cow dung: topsoil: 1:1 media with $30 \times 40 \mathrm{~cm}$ spacing under $30 \%$ shade condition are suitable for turmeric cultivation under dry/semi-arid areas of Sri Lanka.
\end{abstract}

Keywords: Curcuma longa, Media, Shade, Spacing, Turmeric

\section{INTRODUCTION}

Turmeric (Curcuma longa) is an herbaceous perennial plant belonging to the family Zingiberaceae native to tropical South Asia, mainly cultivated in India, China, Bangladesh, and Indonesia. C. longa is a valued spice and aromatic medicinal plant. The rhizomes of Turmeric are commonly used as a flavoring, coloring agent, and preservative. Mainly it is used as a condiment and coloring agent in the food industry. Additionally, it has a great demand in many industries such as the cosmetic, pharmaceutical industry, and ayurvedic medicines (Abeynayaka et al., 2020). Further, it is used to prepare curry mixtures, color in textiles, and prepare specific paints. The principal constituent of Turmeric is Curcumin, which is diferuloylmethane. Other constituents are curcuminoids and an essential oil called zingiberene. The yellow coloring substances are known as curcuminoids (Gayathiri and Narendhiran, 2020).
Turmeric is an essential component of traditional Indian and Chinese medicine. The main active compound curcumin possesses a vast array of pharmacological effects, including antioxidant, anticancer, anti-inflammatory, antimicrobial (antibacterial, antifungal, and antiviral), antidiabetic, antirheumatic, angiogenic, antifertility, wound healing properties and is used in gastrointestinal and respiratory disorders (Chaudhary et al., 2010, Dasgupta and Klein, 2014).

Turmeric is grown in wet and intermediate zones of Sri Lanka, mainly in Kurunegala, Gampaha, Kalutara, Kandy Matale, and Ampara districts, and generally cultivated as a mono-crop and an intercrop under coconut (DEA, 2021). Furthermore, several locally grown varieties are available, not specially identified. Also, there are imported varieties, namely Gunter, Puna, and Madurasi Majal, and they have been mixed with 
local varieties. Currently, turmeric production in Sri Lanka is not self-sufficient. To keep pace with the increased demand, a significant proportion of the local demand is being imported, putting a heavy burden on national income (Abeynayaka et al., 2020).

Moreover, due to the import restrictions imposed by the Government on export agricultural crop products such as ginger, pepper, and Turmeric, farmers showed a significant interest in cultivating such crops. Accordingly, raw turmeric production at 25,506 metric tons in 2020 recorded a remarkable growth of 170.9 percent (Central Bank, 2021). However, to meet increased demand, it is important and urgent to study the feasibility of growing Turmeric in non-conventional areas such as dry and semi-arid areas. Moreover, plenty of lands are available in the dry zone for cultivations, but it is still hardly found that any research has been done on growing Turmeric in dry and semiarid areas of Sri Lanka. However, DEA (2021) stated that successfully growing Turmeric required medium-level shade and $1500 \mathrm{~mm}$ or above annual rainfall.

Further, they stated that Turmeric could be grown in the dry zone under irrigation. Moreover, recent research indicates the effectiveness of planting spacing, growing media, and shade level to the yield and quality performance of Turmeric (Aly et al., 2019; Bhadouria et al., 2014). Therefore, the present research was designed to study the growth and yield performances of Turmeric as affected by different planting spacings, growing media, and shade under dry zone conditions in Sri Lanka.

\section{METHODOLOGY}

\section{Experimental Location}

The experiment was carried out at the research farm of the University of Colombo Institute for Agro-Technology, and Rural Sciences (UCIARS) in Weligatta, Hambanthota, at an altitude of 17 meters above mean sea level and DL5 Agroecological region in Sri Lanka, which is one of the areas where least amount of annual rainfall received.

\section{Experiment design}

The experiment was designed according to the Split plot design with 12 treatment combinations with three replicates, and each replicate contains 40 plants. The main plot consisted of two shade levels as $30 \%$ shade (S1) and without shade (S2), and subplots were assigned three spacing $30 \mathrm{~cm} \times 20 \mathrm{~cm}$, $30 \mathrm{~cm} \times 30 \mathrm{~cm}, 30 \mathrm{~cm} \times 40 \mathrm{~cm}$ respectively for $\mathrm{P} 1$, $\mathrm{P} 2$, and $\mathrm{P} 3$, and two different potting media Cow dung: Topsoil - 1:1 (M1), Cow dung: Topsoil: Sand - 1: 1: 0.5 (M2).

\section{Plant establishment}

Thirty-six beds with $3 \mathrm{~m}$ length and $1 \mathrm{~m}$ width were prepared, and topsoil, sand, cow dung were added to the beds according to the treatments during the bed preparation. Healthy matured finger rhizomes were collected from the UCIARS farm and planted $50 \mathrm{~g}$ per planting hole.

Fertilization was practiced according to the DEA recommendations (Urea $\mathrm{Kg} / \mathrm{ha}$ and MOP $\mathrm{Kg} / \mathrm{ha}$ as a basal and Urea $\mathrm{Kg} / \mathrm{ha}$ and MOP $\mathrm{Kg} / \mathrm{ha}$ as a top dressing, 90 days after planting). Watering was practiced once every two days up to 7 months of planting if there were no rains. Watering frequency was reduced seven months after planting. Weeding was done when necessary.

\section{Data collection}

Plant height, leaf length, and the number of sprouts per plant were taken as growth parameters biweekly, and fresh rhizome yield was taken at harvesting as yield parameters.

\section{Data analysis}

Analysis of data was carried out using ANOVA procedure, and mean comparison was performed using Turkey pair-wise analysis using the MINITAB version 17 to evaluate statistical significance $(\mathrm{P}=0.05)$

\section{RESULTS AND DISCUSSION}

\section{Weather}

The average temperature of the field was $28.33 \mathrm{oC}$ during the growing period. The light intensity of the field was around 38860 lux with $30 \%$ shade and 86160 lux without shade during the growing period of Turmeric.

\section{Growth parameters}

\section{Plant height}

There was no significant interaction of shade, planting spacing, and planting media on plant height. However, there was a significant interaction between shade and media on plant height after 23 weeks of planting up to 31 weeks after planting (Table 1). The height of plants established in cow dung: topsoil; 1:1 media and cow dung: topsoil: sand; 1:1: 0.5 media under shade were significantly higher than the plants established without shade. This might be due to the low light intensity and high relative humidity under the shade net situation (Babu et al., 2019).

\section{Leaf Length}

There was no significant interaction effect of shade, planting spacing, and growing media on the leaf length of turmeric plants. However, there was 

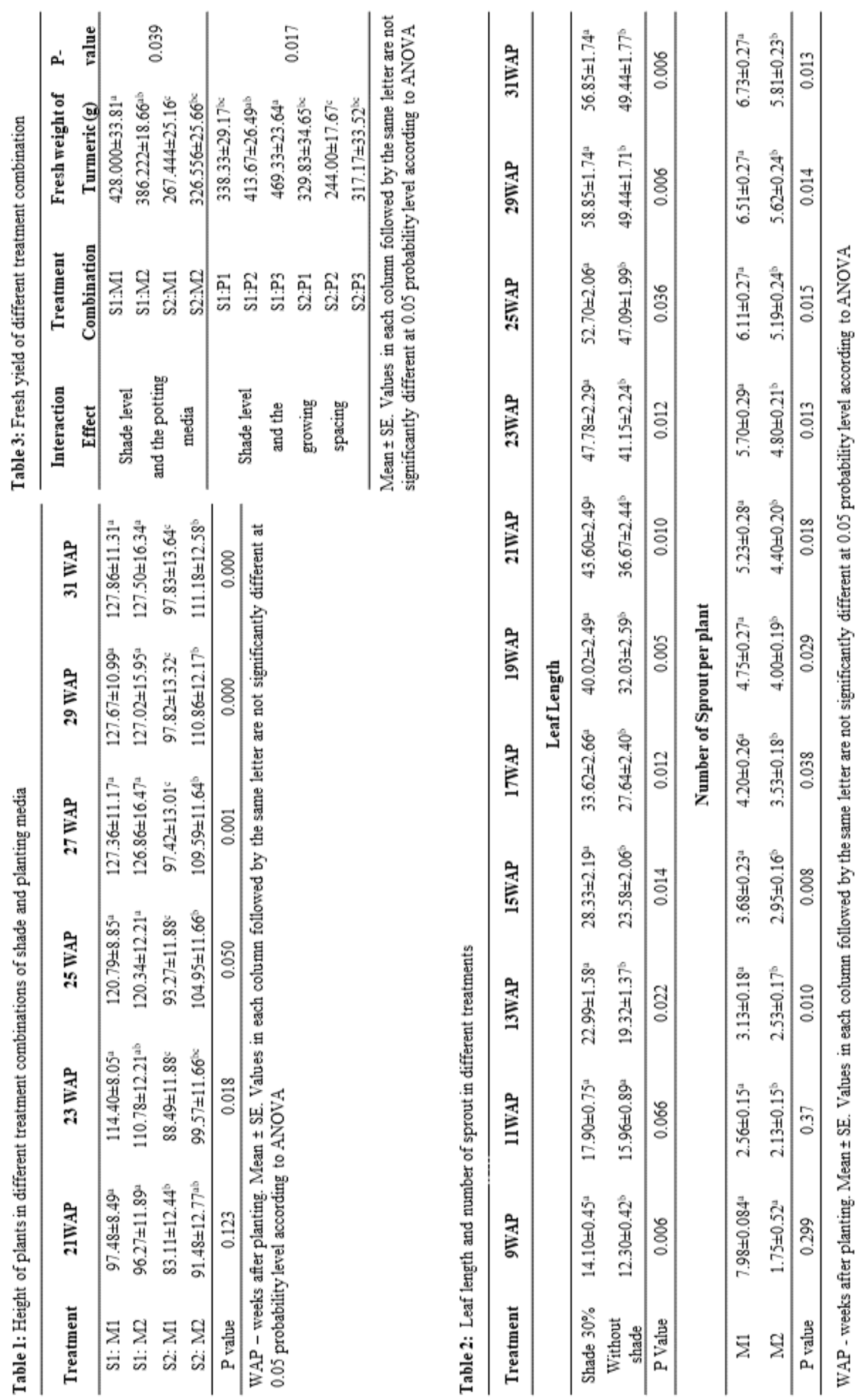
a significant effect of shade on the leaf length of turmeric plants (Table 2). The significantly highest leaf length was recorded from the plants established under $30 \%$ shade from 13 weeks to 31 weeks after planting.

\section{Number of sprouts per plant}

There was no significant interaction effect of shade, planting spacing, and media on the number of turmeric plants sprout. There was a significant effect of growing media on the number of sprouts per plant (Table 2). The significantly highest number of sprouts per plant was recorded from the plants established in cow dung: topsoil; 1:1 media.

\section{Yield Parameters}

\section{Fresh weight of Turmeric}

There was no significant interaction effect of shade, planting spacing, and planting media on the yield of Turmeric. There was a significant interaction effect of shade and growing media on the fresh yield of Turmeric (Table 3). However, there was a significant interaction of shade and planting spacing and shade and growing media on rhizome yield. The significantly highest fresh yield was recorded from the plants established in cow dung: topsoil; 1:1 media under shade. The significantly higher yield was recorded from plants established in $30 \times 40 \mathrm{~cm}$ spacing and $30 \times 30 \mathrm{~cm}$ spacing under shade.

Kiran and colleagues in 2013 studied the effect of plant spacing on vegetative characters and the yield of Turmeric. The study revealed that the spacing 30 x $50 \mathrm{~cm}$ had significantly least days taken to sprouting, maximum plant height, number of leaves per plant, leaf length, leaf diameter, stem per plant, number of fingers per plant, finger length, finger weight, the diameter of the finger and turmeric yield. Further, Bhadouria and colleagues in 2014 and Kumar and Gill in 2009 were observed a significantly high yield with wide spacing $60 \times 20$ $\mathrm{cm}$ and 83,333 plants per ha, respectively.

The present study reveals a significant interaction between shade and media on plant height, a significant effect of shade on the leaf length, and growing media's effect on the number of sprouts on the turmeric plant. Further, it was shown that there was a significant interaction effect of shade and growing media on the fresh yield of Turmeric.

Recent research conducted by Shannon and colleagues in 2019 stated that Turmeric plants established under shade showed a significant increment of plant height, leaf size, and fresh weight of rhizomes. According to Srikrishnah and Sutharsan (2015), the biomass and the yield of turmeric plants cultivated under $50 \%$ shade level were significantly higher than those cultivated in zero shade. The increment of shade level of more than $50 \%$ reduced the amount of solar radiation and caused decreased photosynthesis. Aly and colleagues in 2019 identified that the plant height, number of leaves per plant, leaf area, and dry matter content was higher in the ginger plants established in shade level compared to the plants without any shade. Further, the shade significantly improved the number of tillers per plant and the rhizome weight of ginger, while plants established without any shade showed a reduction in ginger's growth and yield (Aly et al., 2019).

\section{CONCLUSIONS}

Significant yield performance for the growing media was shown by cow dung: topsoil; 1:1from the tested media combination. Suitable plant spacing and shade level for the turmeric cultivation in dry zone area is $30 \mathrm{~cm} \times 40 \mathrm{~cm}$ and $30 \%$ shade condition. Turmeric can be cultivated successfully in the country's driest areas in Hambantota with intensive irrigation and proper shade condition.

\section{REFERENCES}

Abeynayaka, A.A.S.L., Bandara, A.M.K.R., Lankapura, A.I.Y. and Idamekorala, P.R. 2020. Economics of Turmeric Production in Sri Lanka: An Empirical Analysis in Major Turmeric Growing Districts. Asian Journal of Agricultural and Horticultural Research, pp.10-17.

Aly, M.M., El Sawy, A. and El Gendy, R.A. 2019. Comparative study of different shading types on growth and yield of ginger plants. Middle East J, 8(4), pp.1264-1270.

Babu, M.S., Kumar, B.P., Swami, D.V., Krishna, K.U. and Emmanuel, N. 2019. Impact of shade net condition on growth, rhizome and yield characters of ginger. Journal of Pharmacognosy and Phytochemistry, 8(3), pp.3481-3485.

Bhadouria, R.S., Singh, T.K. and Haldar, A. 2014. Effect of interaction on various planting methods and spacing on growth and yield of Turmeric (Curcuma longa L.). Plant Archives, 14(2), pp.1047-1049.

Central Bank. 2021. Annual Report. [Online] Available

at:https://www.cbsl.gov.lk/sites/default/files/cb slweb_documents/publications/annual_report/2 020/en/6_Chapter_02.pdf [Accessed 30 November 2021]

Chaudhary P, Kumar P, Kumar G and Varshney J. 2010. A review on pharmacological activities of Turmeric. Pharmacologyonline, 3, 193-199. 
Dasgupta, A. and Klein, K. 2014. Herbal and Other Dietary Supplements That Are Antioxidants. In: Dasgupta, A. and Klein, K. (eds.) Antioxidants in Food, Vitamins and Supplements. San Diego: Elsevier

Department of Export Agriculture (DEA). 2021. Turmeric [Online] Available at: http://www.dea.gov.lk/turmeric/ [Accessed 15 April 2021]

Gayathiri, M. and Narendhiran, V. 2020. Best Organic Media for Growing Turmeric Minisetts in Protray Nursery. Plant Archives, 20, 3014-3016.

Kiran, M., Bibi, R., Jillani, M.S., Waseem, K., Ullah, G., Javeria, S. and Niamatullah, M. 2013. Effect of plant spacing on profitable yield of Turmeric (Curcuma longa L.). Pakistan Journal of science, 65(4).
Kumar, B. and Gill, B.S. 2011. Growth, yield and quality of Turmeric (Curcuma longa L.) as influenced by planting method, plant density and planting material. Journal of Spices and Aromatic crops, 19(1\&2).

Shannon, D.A., van Santen, E., Salmasi, S.Z., Murray, T.J., Duong, L.T., Greenfield, J.T., Gonzales, T. and Foshee, W. 2019. Shade, establishment method, and varietal effects on rhizome yield and curcumin content in Turmeric in Alabama. Crop Science, 59(6), pp.2701-2710.

Srikrishnah, S. and Sutharsan, S. 2015. Effect of different shade levels on growth and tuber yield of Turmeric (Curcuma longa L.) in the Batticaloa District of Sri Lanka. Am. Euras. J. Agric. Agric. Environ. Sci, 15. 